\title{
Formation of $\mathrm{La}_{1-x} \mathrm{Sr}_{\mathrm{x}} \mathrm{Co}_{1-\mathrm{y}} \mathrm{Fe}_{\mathrm{y}} \mathrm{O}_{3-\delta}$ cathode materials from precursor salts by heating in contact with CGO electrolyte
}

\author{
Can Sindiraç, Sedat Akkurt* \\ Department of Mechanical Engineering, Faculty of Engineering, Izmir Institute of Technology, 35430 Urla, Izmir, \\ Turkey
}

\section{A R T I C L E I N F O}

Article history:

Received 6 May 2016

Received in revised form

14 July 2016

Accepted 15 July 2016

Available online 5 August 2016

Keywords:

SOFC

Cathode material

LSCF

Thermal decomposition

Fuel cell

\begin{abstract}
A B S T R A C T
The purpose of this study is to determine the solid state reactions leading to the formation of $\mathrm{La}_{0.6} \mathrm{Sr}_{0.4} \mathrm{Co}_{0.8} \mathrm{Fe}_{0.2} \mathrm{O}_{3}$ and $\mathrm{La}_{0.6} \mathrm{Sr}_{0.4} \mathrm{Co}_{0.2} \mathrm{Fe}_{0.8} \mathrm{O}_{3}$ which are widely used as cathode material in solid oxide fuel cells (SOFC) from precursor salts. Interactions between the cathode and the electrolyte layers are also investigated while the cathode layer formed upon heating in contact with the surface of cerium-gadolinium oxide (CGO) electrolyte substrates. Almost all combinations of precursor salt mixtures were tested to see if all solid state reactions are completed and what phases eventually formed. Most of the transformation was complete after $1050{ }^{\circ} \mathrm{C}$ heat treatment to yield different mixed oxides. The cathode layer was usually in porous form but was found to spread well over the substrate. Uneven diffusion of La, Sr, Co or Fe into the substrate influenced the stoichiometry of the resulting cathode layer in varying degrees. Fe was found to diffuse into the substrate.
\end{abstract}

๑ 2016 Hydrogen Energy Publications LLC. Published by Elsevier Ltd. All rights reserved.

\section{Introduction}

Production of clean, efficient and environmentally-friendly energy is nowadays one of the biggest challenges. Fuel cells are promising and efficient electrochemical devices that convert chemical energy directly into electrical energy $[1,2]$. Solid oxide fuel cells (SOFC) are environmentally-friendly since no combustion is required unlike conventional power plants, they run on hydrogen and hydrocarbons very efficiently [3]. In principle, a fuel cell operates like a battery. However, unlike a battery, a fuel cell does not run down or require recharging. They produce electricity as long as they are fed oxygen and hydrogen [4]. Hydrogen can be obtained from common fuels such as hydrocarbon or coal [5].

There are different types of fuel cells which are categorized by the type of the electrolyte used [6]. A typical SOFC consists of two porous electrodes which are the anode (negative side), and the cathode (positive side). Both electrodes must be wellseparated by a dense oxide ceramic electrolyte. The operation of the solid oxide fuel cell is simple. Hydrogen is fed to the anode, and oxygen is fed to the cathode [7]. While $\mathrm{O}^{-2}$ ions are transported through the electrolyte from the cathode side to the anode side, electrons flow from the anode through the external circuit to the cathode and by this way an electric current is generated [3]. Also, water $\left(\mathrm{H}_{2} \mathrm{O}\right)$ and heat are

\footnotetext{
* Corresponding author.

E-mail address: sedatakkurt@iyte.edu.tr (S. Akkurt).
} 
produced in the end of reactions [7]. Due to the necessity of maintaining high ionic diffusion rates, the whole system is operated at high temperatures $\left(\mathrm{T}>800^{\circ} \mathrm{C}\right)$ which requires the use of costly materials $[8,9]$.

Significant research is devoted to the improvement of fuel cell materials with the aim of reducing the solid oxide fuel cell (SOFC) operating temperature $\left(800-1000^{\circ} \mathrm{C}\right)$ to less than $800^{\circ} \mathrm{C}$ and hence making intermediate temperature solid oxide fuel cells (IT-SOFC). The advantages of decreasing the operating temperatures are (i) reduction of the cost of the system due to the use of less expensive materials, (ii) increased lifetime of the total system, (iii) reduction in corrosion rates and (iv) faster start up and shut down capability [10-14]. Despite all these benefits, ohmic losses in the electrolyte increase dramatically as the operating temperature is reduced [1]. The electrolyte causes more ohmic losses than the cathode and the anode because of ionic resistivity of the electrolyte is greater. This problem can be solved by reducing the thickness of electrolyte and choosing electrolyte materials of high ionic conductivity [1,15]. Cerium gadolinium oxide (CGO) [16-20], yttria-stabilized zirconia (YSZ) [7,18] are some examples of electrolyte materials which are used for the purpose of minimizing the ohmic losses [21]. Cathode materials are also expected to show good ionic conductivity. Hence, research on new cathode materials with higher ionic conductivity has been underway in recent years. $\mathrm{La}_{1-\mathrm{x}} \mathrm{Sr}_{\mathrm{x}} \mathrm{Co}_{1-\mathrm{y}} \mathrm{Fe}_{\mathrm{y}} \mathrm{O}_{3-\delta}$ cathode material has attracted much attention because of its high ionic conductivity characteristics [22-26].

There are several different synthesis methods that have been developed for preparation of the cathode layer, such as combustion method, solid-state method, sol-gel process, Pechini method, co-precipitation process [27-29]. In ESD (Electro Spray Deposition) method, a precursor salt solution is prepared from different salts to yield a final composition of LSCF after being coated on the heated surface $\left(400{ }^{\circ} \mathrm{C}\right)$ of the electrolyte substrate [17]. However, little is known in the literature about the reactions that take place during rapid heating of the salt solution which evaporates upon contact with the electrolyte substrate. An information regarding the phase evolution in solid salt mixtures via solid state reactions would be a helpful reference in understanding the formation of LSCF cathode materials. In this study, the precursor salts are mixed in solid state and heated at different temperatures. The main goal is to investigate the thermal decomposition and reforming reactions leading to the development of mixed oxide cathode layer (LSCF). When these salts are heated in contact with the CGO substrate they react on the surface. Hence, these interfacial interactions are also studied.

\section{Experimental}

\section{Materials}

Precursor salt powders used in this work were lanthanum (III) nitrate hexahydrate (ALFA-AESAR $>99.99 \%$ ), strontium chloride hexahydrate (ALFA-AESAR $>99 \%$ ), cobalt (II) nitrate hexahydrate (ALFA-AESAR $>97.7 \% \mathrm{~min}$ ) and iron (III) nitrate nonahydrate (ALFA-AESAR >99.99\%) salts. 10 mol\% Gadolinium doped Ceria powder $\left(\mathrm{Ce}_{0.9} \mathrm{Gd}_{0.1} \mathrm{O}\right.$, PRAXAIR $\left.>99.9 \%\right)$ is used for preparing the ceramic electrolyte substrate. Specific surface area of CGO is $6.6 \mathrm{~m}^{2} / \mathrm{g}$. Particle size distribution of CGO powder is $0.4 \mu \mathrm{m}, 0.6 \mu \mathrm{m}$ and $0.9 \mu \mathrm{m}$ for $d_{10}, d_{50}$ and $d_{95}$, respectively. Here, $d_{10}$, for example, means that 10 weight percent of the powder is below the size of $0.4 \mu \mathrm{m}$.

\section{Experimental plan}

Experiments were conducted in five stages:

In the first part, as-received salt powders $\left(\mathrm{La}\left(\mathrm{NO}_{3}\right)_{3} \cdot 6 \mathrm{H}_{2} \mathrm{O}\right.$, $\mathrm{SrCl}_{2} \cdot 6 \mathrm{H}_{2} \mathrm{O}, \mathrm{Co}\left(\mathrm{NO}_{3}\right)_{2} \cdot 6 \mathrm{H}_{2} \mathrm{O}$ and $\left.\mathrm{Fe}\left(\mathrm{NO}_{3}\right)_{3} \cdot 9 \mathrm{H}_{2} \mathrm{O}\right)$ were characterized by scanning electron microscope (SEM), X-ray diffraction (XRD) and thermogravimetric analysis (TGA). In the second stage, these salts were analysed either individually or blended in different combinations. Mixtures of groups of double and triple salts as well as mixtures matching $\mathrm{La}_{0.6} \mathrm{Sr}_{0.4} \mathrm{Co}_{0.8} \mathrm{Fe}_{0.2} \mathrm{O}_{3-\delta}$ (LSCF-6482) and $\mathrm{La}_{0.6} \mathrm{Sr}_{0.4} \mathrm{Co}_{0.2} \mathrm{Fe}_{0.8} \mathrm{O}_{3-\delta}$ (LSCF-6428) compositions were prepared. Salts were mixed in different proportions as listed in Table 1 . The acronyms refer to the first letters of the elemental symbols. L represents $\mathrm{La}\left(\mathrm{NO}_{3}\right)_{3} \cdot 6 \mathrm{H}_{2} \mathrm{O}$, S represents $\mathrm{SrCl}_{2} \cdot 6 \mathrm{H}_{2} \mathrm{O}, \mathrm{C}$ represents $\mathrm{Co}(\mathrm{N}-$ $\left.\mathrm{O}_{3}\right)_{2} \cdot 6 \mathrm{H}_{2} \mathrm{O}$ and $\mathrm{F}$ represents $\mathrm{Fe}\left(\mathrm{NO}_{3}\right)_{3} \cdot 9 \mathrm{H}_{2} \mathrm{O}$ in this study. Likewise, $\mathrm{L}+\mathrm{C}$ represents a mixture of $\mathrm{La}\left(\mathrm{NO}_{3}\right)_{3} \cdot 6 \mathrm{H}_{2} \mathrm{O}$ and $\mathrm{Co}\left(\mathrm{NO}_{3}\right)_{2} \cdot 6 \mathrm{H}_{2} \mathrm{O}$.

In the third stage, powders of precursor salts were blended by hand in Agate mortar and pestle in the order listed in Table 1. These salts were placed into the oven (Nuve Etuv FN 500, Ankara), heated at $55{ }^{\circ} \mathrm{C}$ for $24 \mathrm{~h}$ until throughly dried. The samples were then compacted by uniaxial pressing in a stainless steel die ( $\phi=8 \mathrm{~mm}$ and $\mathrm{P}=20$ bars) using a hydraulic press (Ylldız Hydraulic Press, X5, Izmir, Turkey). In the fourth stage, the CGO electrolyte pellets were prepared similarly but with a larger diameter $(\phi=15 \mathrm{~mm}$ and $\mathrm{h}=2.5 \mathrm{~mm})$. The CGO pellets were sintered in an electrically heated laboratory kiln (Nabertherm LHT 02/17, Germany) at $1300^{\circ} \mathrm{C}$ for $4 \mathrm{~h}$. Then, one of the two flat surfaces of the samples were ground with grinding paper followed by polishing using $6 \mu \mathrm{m}$ and $3 \mu \mathrm{m}$

\section{Table 1 - Sample codes for different salt blends. ${ }^{a}$}

\begin{tabular}{ll}
\hline Sample no. & Sample composition \\
\hline 1 & $\mathrm{~L}$ \\
2 & $\mathrm{~S}$ \\
3 & $\mathrm{C}$ \\
4 & $\mathrm{~F}$ \\
5 & $\mathrm{~L}+\mathrm{C}$ \\
6 & $\mathrm{~S}+\mathrm{C}$ \\
7 & $\mathrm{C}+\mathrm{F}$ \\
8 & $\mathrm{~L}+\mathrm{F}$ \\
9 & $\mathrm{~S}+\mathrm{F}$ \\
10 & $\mathrm{~L}+\mathrm{S}+\mathrm{C}+\mathrm{F}$ \\
11 & $\mathrm{~L}+\mathrm{S}+\mathrm{C}$ \\
12 & $\mathrm{~L}+\mathrm{C}+\mathrm{F}$ \\
13 & $\mathrm{~L}+\mathrm{S}$ \\
14 & $\mathrm{~L}+\mathrm{S}+\mathrm{F}$ \\
15 & $\mathrm{~S}+\mathrm{C}+\mathrm{F}$ \\
16 & $\mathrm{La}_{0.6} \mathrm{Sr}_{0.4} \mathrm{Co}_{0.8} \mathrm{Fe}_{0.2} \mathrm{O}_{3-\delta}$ \\
17 & $\mathrm{La}_{0.6} \mathrm{Sr}_{0.4} \mathrm{Co}_{0.2} \mathrm{Fe}_{0.8} \mathrm{O}_{3-\delta}$ \\
\hline
\end{tabular}

a Sample numbers 5 to 15 were prepared in one to one molar ratio. Sample number 16 was prepared in 6:4:8:2 M ratio. Sample number 17 was prepared in 6:4:2:8 $\mathrm{M}$ ratio. 
diamond suspensions to obtain a well-polished uniform surface. Just after preparing the cathode and electrolyte materials, solid state reaction experiments were conducted as the fifth stage of the experiments. Pressed salt mixture pellets placed on top of the polished CGO pellets were heated in the furnace by a heating schedule as shown in Fig. 1. After thermal treatment, pellet couples (diffusion couples) were removed from the furnace and cut in half by hand to reveal the cross section (Fig. 2). Finally, samples were ready for characterization.

\section{Characterization}

The interfaces between LSCF and electrolyte were investigated by scanning electron microscopy (SEM) using FEI Quanta 250 FEG equipment. The acceleration voltage was $20 \mathrm{kV}$. Backscattered electron image (BSE) was used for observation. Crystal structures of the samples were analysed by using Philips X'Pert Pro X-ray diffraction (XRD) device with $\mathrm{Cu}-\mathrm{K} \alpha$ radiation $(\lambda=1.542 \mathrm{~nm})$ with a step size of 0.0330 and a step counting time of $5.05 \mathrm{~s}$ in the Bragg-Brentano geometry from $5^{\circ}$ to $80^{\circ}$. X'Pert Graphics \& Identity software was used to analyse normalized XRD data.

To determine the thermal decomposition temperatures, thermogravimetric analysis (TGA) was performed on asreceived powders of $\mathrm{La}\left(\mathrm{NO}_{3}\right)_{3} \cdot 6 \mathrm{H}_{2} \mathrm{O}, \mathrm{SrCl}_{2} \cdot 6 \mathrm{H}_{2} \mathrm{O}, \mathrm{Co}(\mathrm{N}$ $\left.\mathrm{O}_{3}\right)_{2} \cdot 6 \mathrm{H}_{2} \mathrm{O}, \mathrm{Fe}\left(\mathrm{NO}_{3}\right)_{2} \cdot 9 \mathrm{H}_{2} \mathrm{O}$, and their blended combinations by using Perkin Elmer Diamond device under nitrogen atmosphere $\left(20 \mathrm{ml} / \mathrm{min} \mathrm{N}_{2}\right)$. Samples were heated from $25{ }^{\circ} \mathrm{C}$ to $900{ }^{\circ} \mathrm{C}$ at a heating rate of $10^{\circ} \mathrm{C} / \mathrm{min}$.

\section{Results and discussion}

In this study, experiments were conducted to understand the phase evolution during heating of different mixtures of precursor salts in solid state. Another purpose was to understand the interactions at the interfaces between these mixtures and the electrolyte substrate. Results of XRD, SEM and TGA analysis of the as-received and heat treated samples are given in this section.

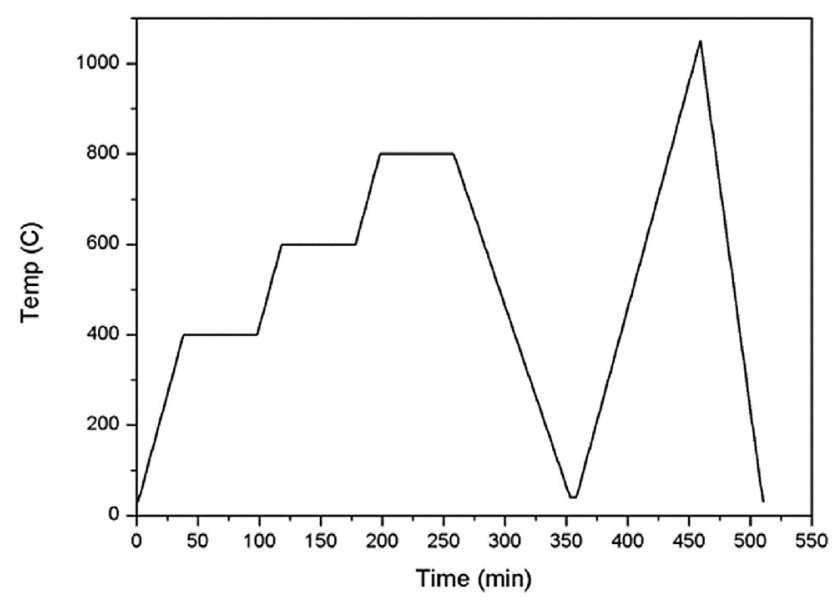

Fig. 1 - Heating schedule for LSCF precursors.

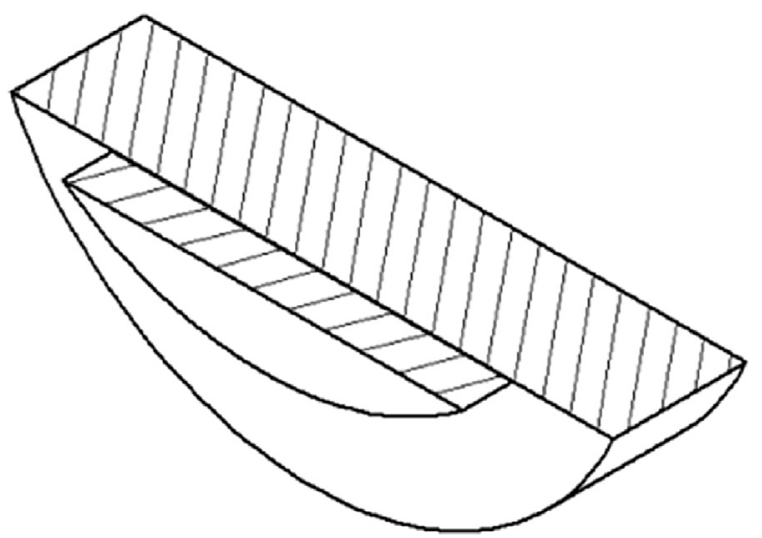

Fig. 2 - Samples are broken by hand to reveal fracture cross sections.

TGA analysis results of as-received powders are shown in Fig. 3(a). As expected, there were several different temperatures at which significant weight loss occurred upon heating of the salts. L salt transformed completely into oxide at $650^{\circ} \mathrm{C}$. The temperatures of complete transformation to oxide and the final products after conversion into oxide after high temperature heat treatment are listed in Table 2. These findings agreed well with the literature [30-33]. Thirteen different combinations of as-received powder mixtures were prepared and analysed by TGA (Table 1 and Fig. 3). TGA analyses of the mixtures with two ingredients are shown in Fig. 3(b). The temperatures at which the final weight loss took place was found to be higher for the triple salt mixtures than the plain ingredients (Fig. 3(c)). Thermal decomposition curves of the mixtures of LSCF in 5:5:5:5, 6:4:8:2 and 6:4:2:8 $\mathrm{M}$ ratio are shown in Fig. 3(d). Final weight loss of LSCF in $5555 \mathrm{M}$ ratio was around $845^{\circ} \mathrm{C}$ close to expectation. Final decomposition of the other two samples were at $910^{\circ} \mathrm{C}$ and $1000^{\circ} \mathrm{C}$ for LSCF in 6482 and 6428, respectively. Both curves were quite similar after $220^{\circ} \mathrm{C}$ and they had nearly the same final weight loss in the end of decomposition.

Salt mixtures were heated in contact with CGO substrates to observe the interactions at the interface between the cathode and the electrolyte. Samples were broken by hand to reveal the interface.

The substrate was always underneath the cathode pellet. In most experiments, the cathode pellets partially fused and were well-spread on the substrates. In few samples, the molten cathode layer was slightly foamed but was still in good contact with the substrate surface. Fig. 4 shows the SEM micrograph of the interface between CGO electrolyte substrate and LSCF salt mixtures as observed on the fractured cross section. Different mixtures of $\mathrm{La}\left(\mathrm{NO}_{3}\right)_{3} \cdot 6 \mathrm{H}_{2} \mathrm{O}+$ $\mathrm{SrCl}_{2} \cdot 6 \mathrm{H}_{2} \mathrm{O}+\mathrm{Co}\left(\mathrm{NO}_{3}\right)_{2} \cdot 6 \mathrm{H}_{2} \mathrm{O}+\mathrm{Fe}\left(\mathrm{NO}_{3}\right)_{3} \cdot 9 \mathrm{H}_{2} \mathrm{O}$ salts were blended in (a) 5555, (b) 6482 and (c) 6428 stoichiometry. Although, perovskite phase is obtained for both 6428 and 5555; both samples failed to produce the relevant LSCF compounds because of uneven diffusion of $\mathrm{La}, \mathrm{Sr}, \mathrm{Co}$ and $\mathrm{Fe}$ into the substrate which disturbed the stoichiometry. Similar observation was also made in the literature [34]. The number of salt mixture combinations that were heated, cut and SEM-analysed was thirteen but only three of them are given here for 


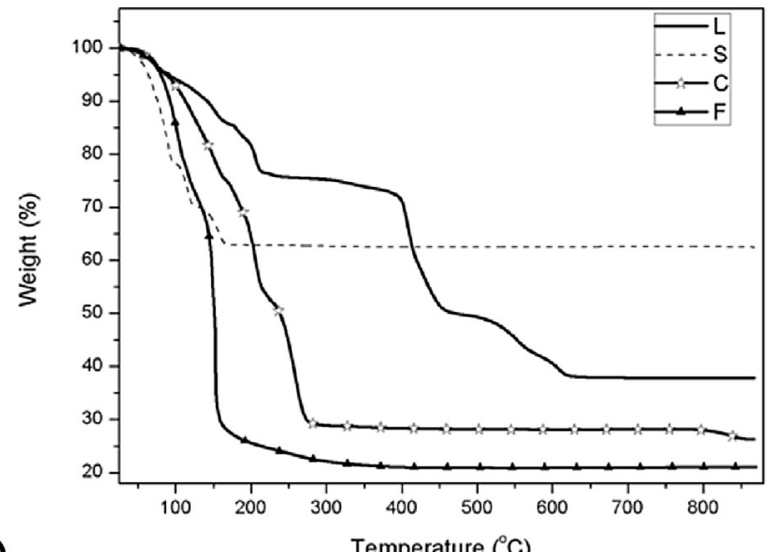

a)

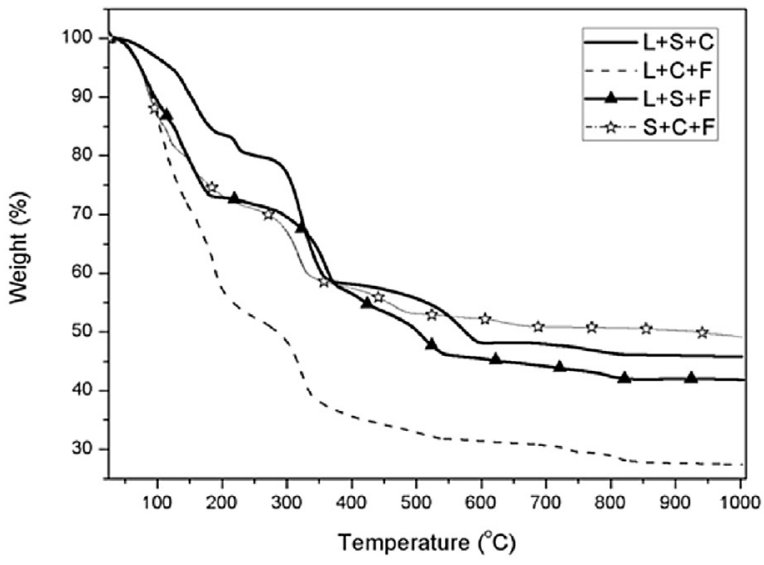

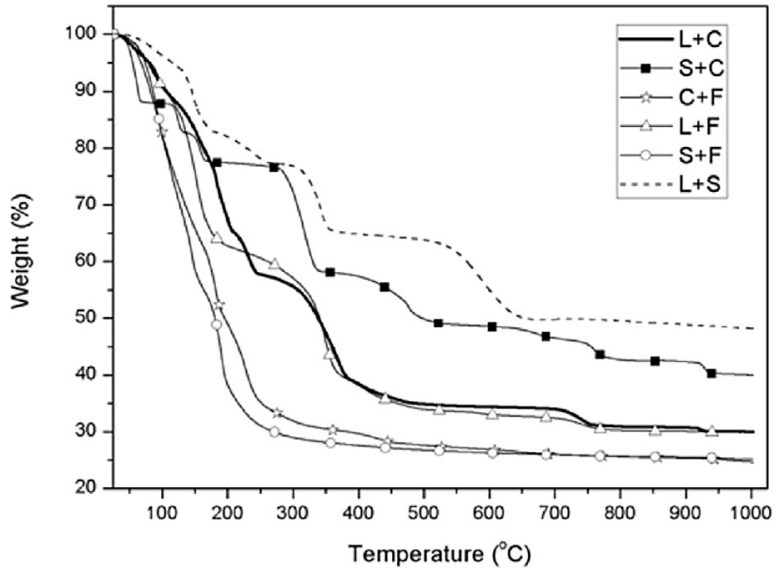

b)

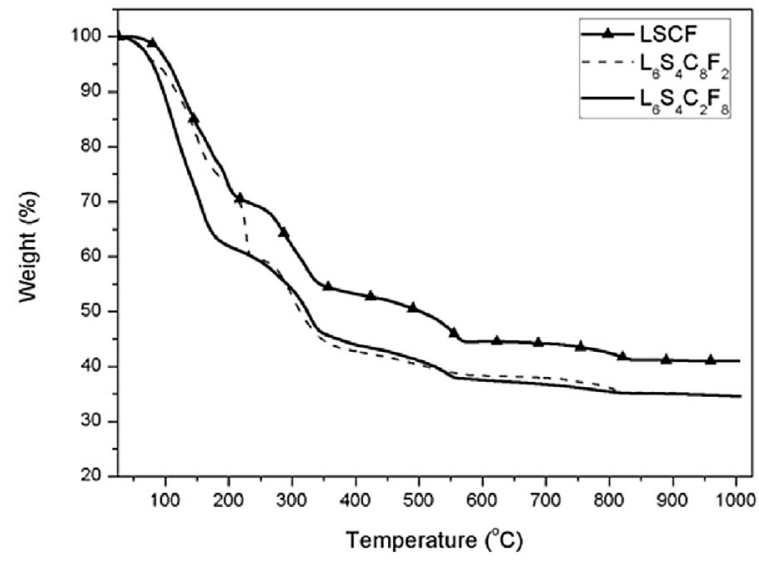

Fig. 3 - (a): TGA analyses of $\mathrm{La}\left(\mathrm{NO}_{3}\right)_{3} \cdot 6 \mathrm{H}_{2} \mathrm{O}, \mathrm{SrCl}_{2} \cdot 6 \mathrm{H}_{2} \mathrm{O}, \mathrm{Co}\left(\mathrm{NO}_{3}\right)_{2} \cdot 6 \mathrm{H}_{2} \mathrm{O}$ and $\mathrm{Fe}\left(\mathrm{NO}_{3}\right)_{3} \cdot 9 \mathrm{H}_{2} \mathrm{O}$ precursor salts. (b): TGA analyses of mixtures with two ingredients. (c): TGA analyses of mixtures with three ingredients. (d): TGA analysis of mixture of $\mathrm{La}\left(\mathrm{NO}_{3}\right)_{3} \cdot 6 \mathrm{H}_{2} \mathrm{O}+\mathrm{SrCl}_{2} \cdot 6 \mathrm{H}_{2} \mathrm{O}+\mathrm{Co}\left(\mathrm{NO}_{3}\right)_{2} \cdot 6 \mathrm{H}_{2} \mathrm{O}+\mathrm{Fe}\left(\mathrm{NO}_{3}\right)_{3} \cdot 9 \mathrm{H}_{2} \mathrm{O}$ in different proportions.

Table 2 - Temperatures at which last weight loss occurred in as-received precursor salts upon heating. Final products were identified by XRD.

\begin{tabular}{|c|c|c|}
\hline Material & $\mathrm{T}\left({ }^{\circ} \mathrm{C}\right)$ & Final product \\
\hline $\mathrm{La}\left(\mathrm{NO}_{3}\right)_{3} \cdot 6 \mathrm{H}_{2} \mathrm{O}$ & 640 & $\mathrm{La}_{2} \mathrm{O}_{3}$ \\
\hline $\mathrm{SrCl}_{2} \cdot 6 \mathrm{H}_{2} \mathrm{O}$ & 170 & $\mathrm{SrCl}_{2}$ \\
\hline $\mathrm{Co}\left(\mathrm{NO}_{3}\right)_{2} \cdot 6 \mathrm{H}_{2} \mathrm{O}$ & 860 & $\mathrm{CoO}$ \\
\hline $\mathrm{Fe}\left(\mathrm{NO}_{3}\right)_{3} \cdot 9 \mathrm{H}_{2} \mathrm{O}$ & 400 & $\mathrm{Fe}_{3} \mathrm{O}_{4}$ \\
\hline
\end{tabular}

the sake of brevity. Cathode layers were found to bond well to the substrate.

The blends coded 5555, 6482 and 6428 were compressed, placed on CGO disc and heated at $1050{ }^{\circ} \mathrm{C}$ to analyse any interfacial reactions.

In order to better understand the phase evolution during heat treatment of the salt mixtures as well as their interaction with the electrolyte substrate, pellets of cathode salts and the electrolyte were heated in air in contact. All thirteen different samples were blended, dried at $55^{\circ} \mathrm{C}$ for $12 \mathrm{~h}$ and analysed by $\mathrm{XRD}$. In addition, the same samples were further heat-treated (Fig. 1) on top of a CGO substrate disc (Fig. 2) at $800{ }^{\circ} \mathrm{C}$ before being analysed by XRD. Figs. 5-7 shows the XRD patterns of all mixtures listed in Table 1. Even at these low temperatures $\left(55^{\circ} \mathrm{C}\right)$ most of the salts were found to lose their chemically bound water already. Interestingly, in S $+\mathrm{C}$ mixture $\mathrm{Sr}$ and $\mathrm{Co}$ salts were observed to swap their anions. In other words, $\mathrm{SrCl}_{2} \cdot 6 \mathrm{H}_{2} \mathrm{O}$ compound transformed into anhydrous $\mathrm{Sr}\left(\mathrm{NO}_{3}\right)_{2}$ while $\mathrm{Co}\left(\mathrm{NO}_{3}\right)_{2} \cdot 6 \mathrm{H}_{2} \mathrm{O}$ transformed into $\mathrm{CoCl}_{2} \cdot 6 \mathrm{H}_{2} \mathrm{O}$. When $\mathrm{SrCl}_{2} \cdot 6 \mathrm{H}_{2} \mathrm{O}$ is mixed with $\mathrm{La}\left(\mathrm{NO}_{3}\right)_{3} \cdot 6 \mathrm{H}_{2} \mathrm{O}$ or $\mathrm{Fe}\left(\mathrm{NO}_{3}\right)_{2} \cdot 9 \mathrm{H}_{2} \mathrm{O}$ and heated at $55^{\circ} \mathrm{C}, \mathrm{Sr}\left(\mathrm{NO}_{3}\right)_{2}$ formed. No XRD peaks were observed for La or Fe salts. This may be due to the loss of crystal structure upon heating and subsequent transformation into an amorphous state. Peaks for $\left(\mathrm{SrNO}_{3}\right)_{2}$ were observed in all mixtures that contained Sr. In mixtures $\mathrm{S}+\mathrm{F}, \mathrm{L}+\mathrm{S}$ and $\mathrm{S}+\mathrm{C}+\mathrm{F}$ no other peaks were observed because the crystal structures of salts of $\mathrm{La}$, Co and Fe collapsed after the loss of their chemically bound water. As expected, mixtures with the four salts of $\mathrm{La}\left(\mathrm{NO}_{3}\right)_{3} \cdot 6 \mathrm{H}_{2} \mathrm{O}+\mathrm{SrCl}_{2} \cdot 6 \mathrm{H}_{2} \mathrm{O}+\mathrm{Co}\left(\mathrm{NO}_{3}\right)_{2}$. $6 \mathrm{H}_{2} \mathrm{O}+\mathrm{Fe}\left(\mathrm{NO}_{3}\right)_{3} \cdot 9 \mathrm{H}_{2} \mathrm{O}$ did not react to form any mixed oxides at this temperature $\left(55^{\circ} \mathrm{C}\right)$. A high temperature treatment was therefore necessary to form the desired mixed oxides from the salts.

The salt mixtures that were heated on top of CGO substrate at $800{ }^{\circ} \mathrm{C}$ following the heating schedule of Fig. 1 were analysed by XRD. Figs. 8-10 shows the XRD patterns of all mixtures of $\mathrm{L}+\mathrm{S}+\mathrm{C}+\mathrm{F}$ as listed in Table 1. The following observations were made about Figs. 8-10. Salts decomposed upon heating. Only $\mathrm{La}(\mathrm{OH})_{3}$ and $\mathrm{LaOCl}$ were the non-oxides that were still present after the $1050^{\circ} \mathrm{C}$ heat treatment. Dual mixtures produced dual mixed oxides and triple mixtures 
a)
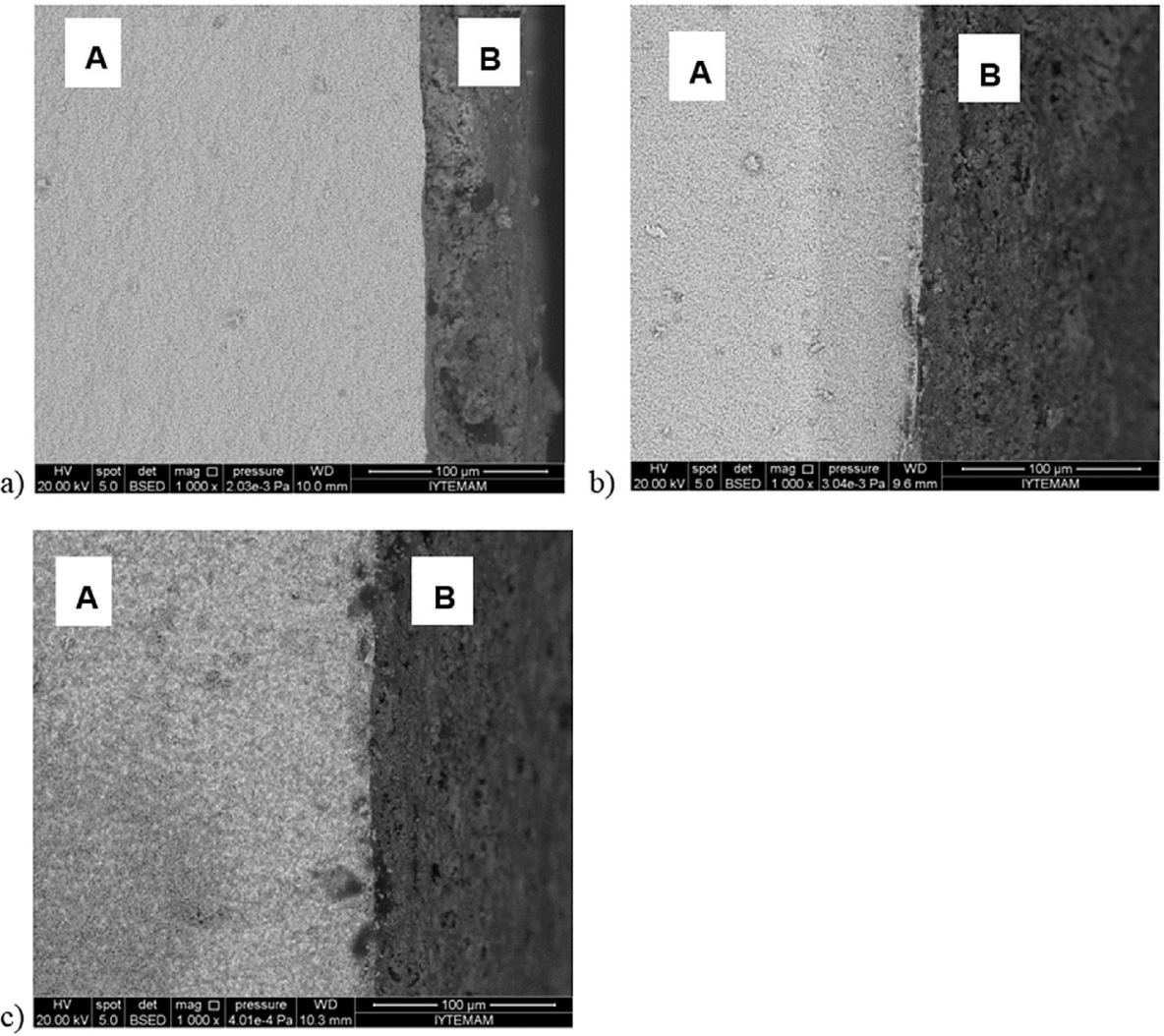

Fig. 4 - SEM images of the cross section of CGO electrolyte and LSCF cathode with (a) 5555 (b) 6482 (c) 6428 stoichiometry. A represents CGO substrate and B represents cathode layers.

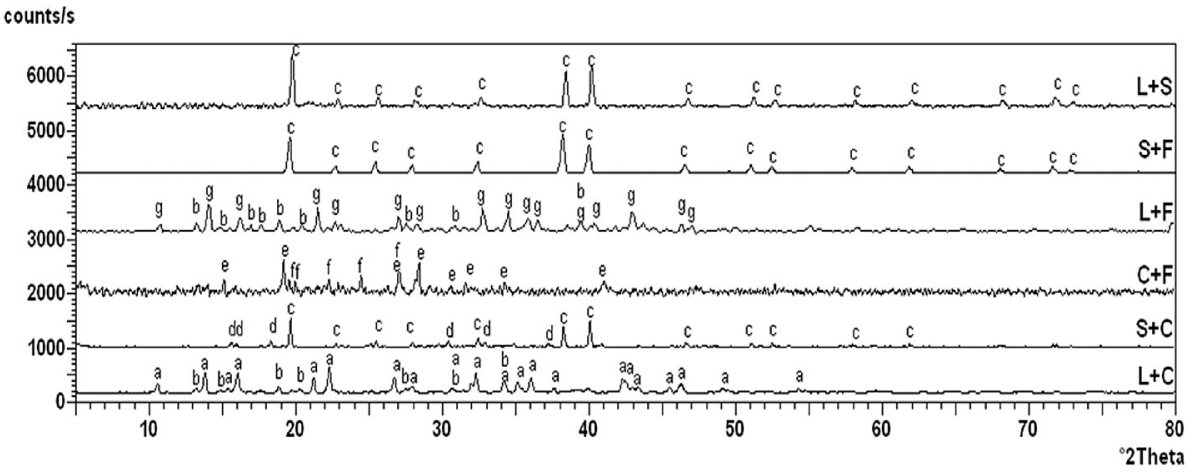

Fig. 5 - XRD analyses of all mixtures before high temperature heat treatment but after $55^{\circ} \mathrm{C}$ heating. Step sizes used during XRD measurements were $\mathbf{0 . 1 3 3}$ for $\mathbf{L}+\mathbf{F}$ and $\mathbf{C}+\mathbf{F}$ and $\mathbf{0 . 0 3 3}$ for other samples. Peaks are named as follows: $\mathbf{a}$ ) $\mathrm{La}_{2} \mathrm{Co}_{3}\left(\mathrm{NO}_{3}\right)_{12} \cdot 24 \mathrm{H}_{2} \mathrm{O}$ b) La( $\left(\mathrm{NO}_{3}\right)_{3}$ c) $\mathrm{Sr}\left(\mathrm{NO}_{3}\right)_{2}$ d) $\mathrm{CoCl}_{2} \cdot 6 \mathrm{H}_{2} \mathrm{O}$ e) $\left.\left.\mathrm{Co}\left(\mathrm{NO}_{3}\right)_{2} \cdot 6 \mathrm{H}_{2} \mathrm{O} \mathrm{f}\right) \mathrm{Fe}\left(\mathrm{NO}_{3}\right)_{2} \cdot 9 \mathrm{H}_{2} \mathrm{O} \mathrm{g}\right) \mathrm{LaFe}\left(\mathrm{NO}_{3}\right)_{6} \cdot 12 \mathrm{H}_{2} \mathrm{O}$.

mostly produced triple mixed oxides. High temperatures, therefore, enabled the formation of new mixed oxides from the dissociating precursor salts as expected. $\mathrm{L}+\mathrm{C}, \mathrm{C}+\mathrm{F}, \mathrm{L}+\mathrm{F}$, $\mathrm{S}+\mathrm{F}, \mathrm{L}+\mathrm{S}$ mixtures produced dual mixed oxides like $\mathrm{LaCoO}_{3}$, $\mathrm{CoFe}_{2} \mathrm{O}_{4}, \mathrm{LaFeO}_{3}, \mathrm{Sr}_{3} \mathrm{Fe}_{2} \mathrm{O}_{3}, \mathrm{La}_{2} \mathrm{SrO}_{3}$, respectively. In $\mathrm{S}+\mathrm{C}$ mixture only $\mathrm{CoO}$ formed. No SrO was observed for this sample. In addition to their dual mixed oxides, $\mathrm{L}+\mathrm{C}$ and $\mathrm{L}+\mathrm{F}$ mixtures also contained some unreacted $\mathrm{La}(\mathrm{OH})_{3}$ and $\mathrm{La}_{2} \mathrm{O}_{3}$, respectively. In triple mixtures like $\mathrm{L}+\mathrm{S}+\mathrm{C}, \mathrm{L}+\mathrm{C}+\mathrm{F}$, $\mathrm{L}+\mathrm{S}+\mathrm{F}$ and $\mathrm{S}+\mathrm{C}+\mathrm{F}$ mixed compounds like $\mathrm{La}_{0.5} \mathrm{Sr}_{0.5} \mathrm{CoO}_{3-\delta}$,
$\mathrm{LaCoO}_{3}, \mathrm{La}_{0.6} \mathrm{Sr}_{0.4} \mathrm{FeO}_{3-\delta}$ and $\mathrm{Sr}_{3} \mathrm{Fe}_{2} \mathrm{O}_{5} \mathrm{Cl}_{2}$, respectively formed. Sample $\mathrm{L}+\mathrm{C}+\mathrm{F}$ also contained some $\mathrm{La}(\mathrm{OH})_{3}$. XRD analysis of sample $\mathrm{L}+\mathrm{C}+\mathrm{F}$ revealed strong peaks for rhombohedral $\mathrm{LaCoO}_{3}$ crystals (JCPDS\# 86-1665 labelled 'a' in Fig. 9) and $\mathrm{LaCo}_{0.42} \mathrm{Fe}_{0.58} \mathrm{O}_{3-\delta}$ (ICSD\# 156486 labelled 'j' in Fig. 9). Analysis of quadruple mixture samples also showed the presence of an oxychloride ( $\mathrm{LaOCl}$ ) in addition to some of the mixed oxides. The oxychlorides have been reported in the literature to survive high temperatures of e.g. $>800^{\circ} \mathrm{C}$ [35]. Analysis of sample 6482 revealed the successful formation of 


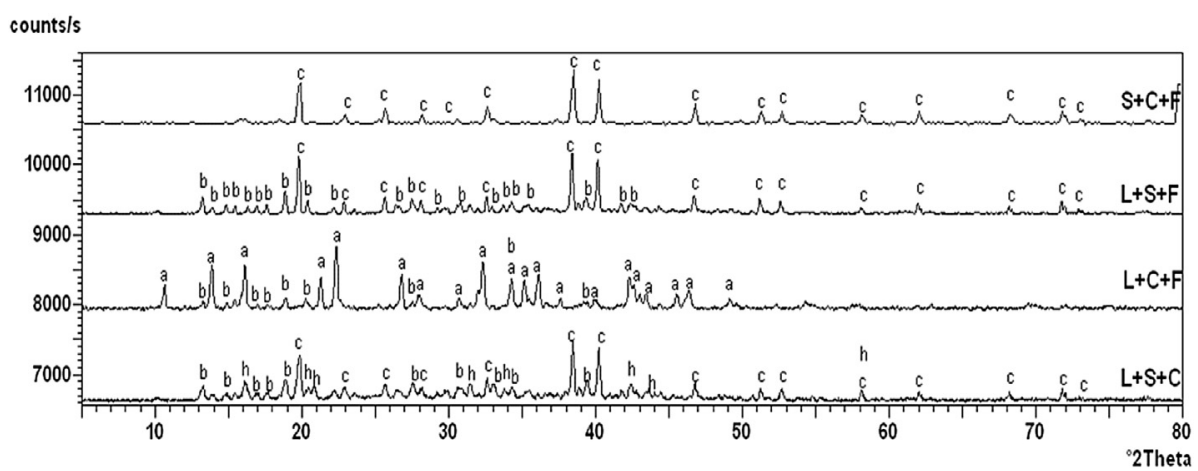

Fig. 6 - XRD analyses of all mixtures before high temperature heat treatment but after $55^{\circ} \mathrm{C}$ heating. Step sizes used during XRD measurements were 0.033 for all samples. Peaks are named as follows: a) $\mathrm{La}_{2} \mathrm{Co}_{3}\left(\mathrm{NO}_{3}\right)_{12} \cdot 24 \mathrm{H}_{2} \mathrm{O}$ b) $\left.\left.\mathrm{La}\left(\mathrm{NO}_{3}\right)_{3} \mathrm{c}\right) \mathrm{Sr}\left(\mathrm{NO}_{3}\right)_{2} \mathrm{~h}\right)$ $\mathrm{CoCl}_{2} \cdot 2 \mathrm{H}_{2} \mathrm{O}$.

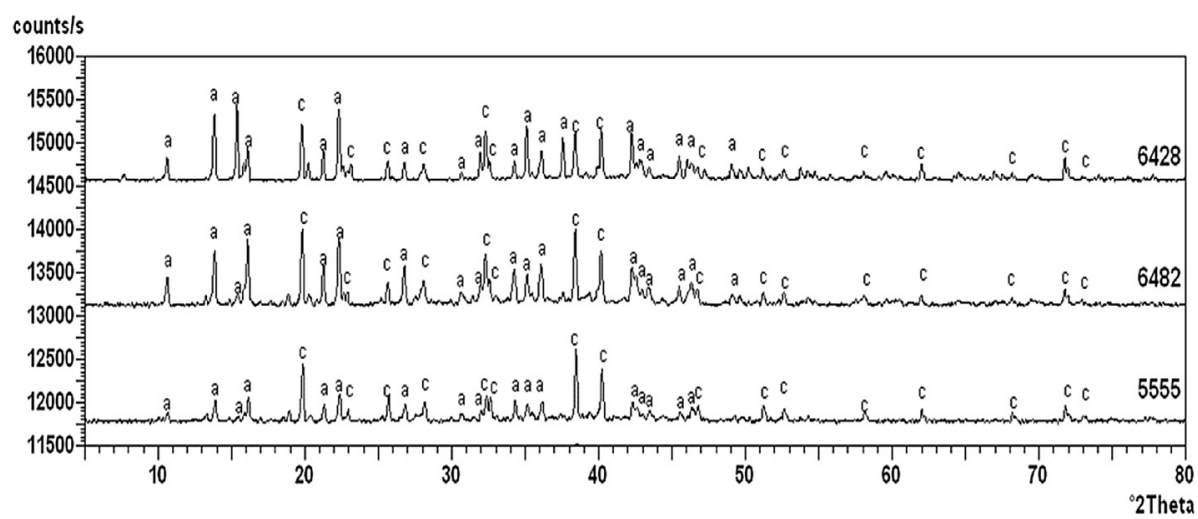

Fig. 7 - XRD analyses of all mixtures before high temperature heat treatment but after $55^{\circ} \mathrm{C}$ heating. Step sizes used during XRD measurements were 0.033 for all samples. Peaks are named as follows: a) $\left.\mathrm{La}_{2} \mathrm{Co}_{3}\left(\mathrm{NO}_{3}\right)_{12} \cdot 24 \mathrm{H}_{2} \mathrm{O} \mathrm{c}\right) \mathrm{Sr}\left(\mathrm{NO}_{3}\right)_{2}$.

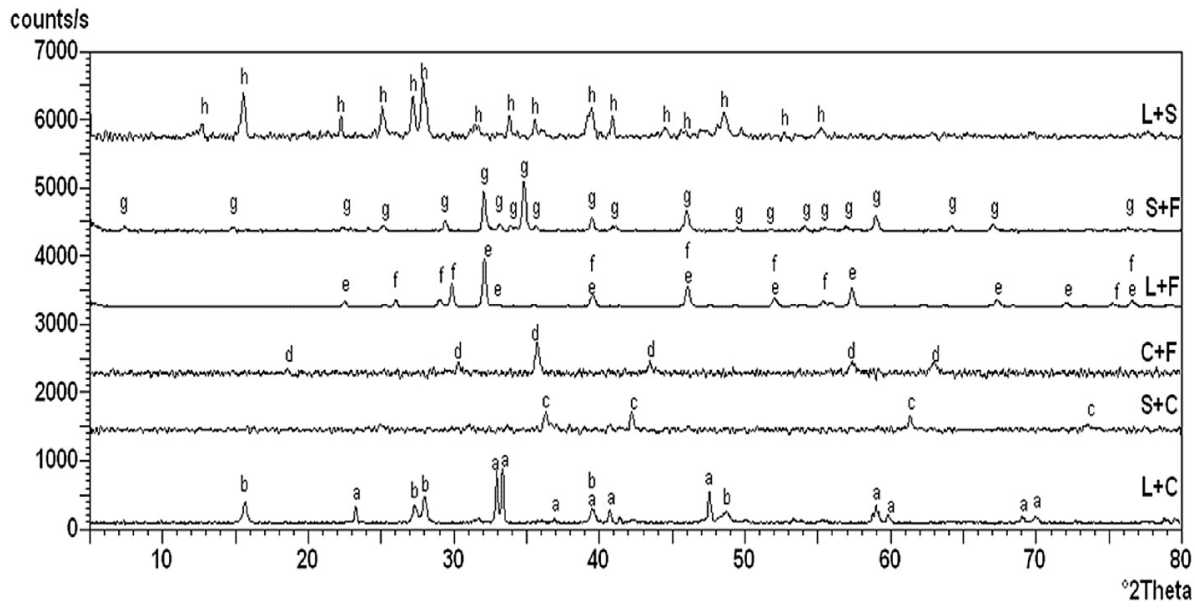

Fig. 8 - XRD analyses of all mixtures after heat treatment on top of CGO substrate. Step sizes used during XRD measurements were 0.033 for all samples. Peaks are named as follows: a) $\mathrm{LaCoO}_{3}$ b) $\mathrm{La}(\mathrm{OH})_{3}$ c) $\mathrm{CoO} \mathrm{d} \mathrm{CoFe}_{2} \mathrm{O}_{4}$ e) $\mathrm{LaFeO}_{3} \mathrm{f}$ ) $\left.\left.\mathrm{La}_{2} \mathrm{O}_{3} \mathrm{~g}\right) \mathrm{Sr}_{3} \mathrm{Fe}_{2} \mathrm{O}_{3} \mathrm{~h}\right) \mathrm{La}_{2} \mathrm{SrO}_{3}$.

$\mathrm{La}_{0.6} \mathrm{Sr}_{0.4} \mathrm{Co}_{0.8} \mathrm{Fe}_{0.2} \mathrm{O}_{3-\delta}$ mixed oxide (JCPDS card No: 48-0124). The peaks for this mixed oxide were quite broad indicating the presence of nano-sized crystals. The average crystallite size of the $\mathrm{La}_{0.6} \mathrm{Sr}_{0.4} \mathrm{Co}_{0.8} \mathrm{Fe}_{0.2} \mathrm{O}_{3-\delta}$ was estimated using Scherrer's equation: $\mathrm{d}=0.94 \lambda /(\beta \cos \theta)$

where $d$ is the average crystallite size of the phase under investigation, $\lambda$ is the wavelength of the radiation used 


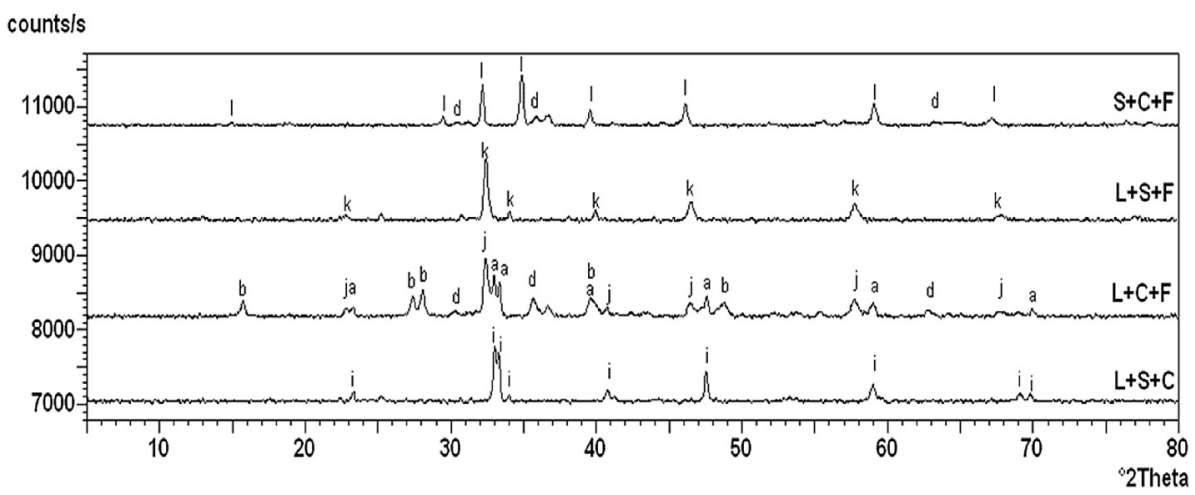

Fig. 9 - XRD analyses of all mixtures after heat treatment on top of CGO substrate. Step sizes used during XRD measurements were 0.033 for all the samples. Peaks are named as follows: b) $\mathrm{La}(\mathrm{OH})_{3}$ d) $\mathrm{CoFe}_{2} \mathrm{O}_{4}$ i) $\mathrm{La}_{0.5} \mathrm{Sr}_{0.5} \mathrm{CoO}_{3} \mathrm{j}$ ) $\left.\mathrm{LaCo}_{0.42} \mathrm{Fe}_{0.58} \mathrm{O}_{3} \mathrm{k}\right) \mathrm{La}_{0.6} \mathrm{Sr}_{0.4} \mathrm{FeO}_{3}$ l) $\mathrm{Sr}_{2} \mathrm{CoFeO}_{5} \mathrm{Cl}_{2}$.

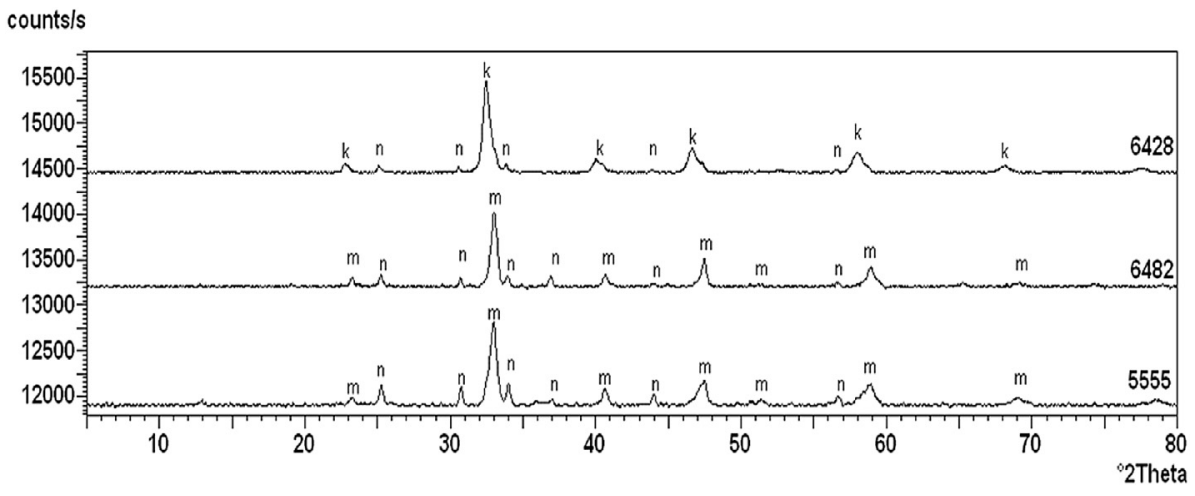

Fig. 10 - XRD analyses of all mixtures after heat treatment on top of CGO substrate. Step sizes used during XRD measurements were $\mathbf{0 . 0 3 3}$ for all the samples. Peaks are named as follows: $\mathrm{k}$ ) $\mathrm{La}_{0.6} \mathrm{Sr}_{0.4} \mathrm{FeO}_{3} \mathrm{~m} \mathrm{La}_{0.6} \mathrm{Sr}_{0.4} \mathrm{Co}_{0.8} \mathrm{Fe}_{0.2} \mathrm{O}_{3} \mathrm{n}$ ) LaOCl.

(1.542 $\AA$ ), $\beta$ is the full width at half maximum (FWHM) of the diffraction peak, and $\theta$ is the angle of diffraction. Average crystallite size of the $\mathrm{La}_{0.6} \mathrm{Sr}_{0.4} \mathrm{Co}_{0.8} \mathrm{Fe}_{0.2} \mathrm{O}_{3-\delta}$ was calculated to be approximately $12 \mathrm{~nm}$.

The XRD charts for the 5555 and 6428 mixture samples showed characteristic peaks of $\mathrm{La}_{0.6} \mathrm{Sr}_{0.4} \mathrm{Co}_{0.8} \mathrm{Fe}_{0.2} \mathrm{O}_{3-\delta}$ (6482) and $\mathrm{La}_{0.6} \mathrm{Sr}_{0.4} \mathrm{FeO}_{3-\delta}$, respectively. These mixed oxides had compositions different from the desired stoichiometry possibly due to loss of Fe ions into CGO substrate via diffusion during extended heating durations [34]. There is a delicate balance between the molar ratios of the component ions. When the mixed oxide is lean or rich with regard to any of the ions, the stoichiometry is rapidly lost. SEM analysis showed that Fe diffused well into the electrolyte more in the LSCF 6428 sample hindering the eventual formation of $\mathrm{La}_{0.6} \mathrm{Sr}_{0.4} \mathrm{Co}_{0.2} \mathrm{Fe}_{0.8} \mathrm{O}_{3-\delta}$.

\section{Conclusions}

Experiments were done to investigate the formation of $\mathrm{La}_{1-\mathrm{x}} \mathrm{Sr}_{\mathrm{x}} \mathrm{Co}_{1-\mathrm{y}} \mathrm{Fe}_{\mathrm{y}} \mathrm{O}_{3-\delta}$ cathode materials and their interaction with electrolyte substrates for potential IT-SOFC applications.
Decompositions of the salt powders on electrolyte substrate were studied using TGA, SEM and XRD to understand the reactions that take place during heating as well as to see how new phases evolve. Data in the literature was confirmed as far as the decomposition of salts alone is considered. But when these salts were mixed in different combinations some interesting findings were observed. 13 different combinations of LSCF salt mixtures were prepared and analysed by SEM, XRD and TGA before and after heat treatment. From SEM analyses it was found that there was some diffusion from the cathode layer into the substrate. However, there was some uneven diffusion into the CGO substrate when the salt blend with LSCF 6428 and 5555 stoichiometry was used. This led to the formation of new mixed oxides with stoichiometries different from the targeted values. The cathode layers in most of the samples formed well to cover the substrate surface. These layers appeared to be porous enough and uniform to satisfy conditions for electrochemical reaction for oxygen reduction. Based on XRD analyses it was found that most salts lost their chemically bound water even at a $55{ }^{\circ} \mathrm{C}$ thermal treatment and transformed into an amorphous state. As expected, none of the samples could form an oxide at this temperature. Sr and Co exchanged between nitrate and 
chloride salts. $\mathrm{Sr}\left(\mathrm{NO}_{3}\right)_{2}$ was observed in a crystal form in all samples that contained $\mathrm{SrCl}_{2} \cdot 6 \mathrm{H}_{2} \mathrm{O}$ before heating. When the samples were heated at $1050^{\circ} \mathrm{C}$, however, mixed oxides could be formed via solid state reactions. Samples containing all four salts in different proportions ended up with mixed oxides and an oxychloride. Nanometric sized crystals of LSCF $(\mathrm{d}=12 \mathrm{~nm}$ ) could finally be formed successfully via solid state synthesis in 6482 stoichiometry. It was, however, not possible to form the desired oxide in 6428 and 5555 stoichiometries. When mixed salts are heated in contact with CGO, some ions are lost by diffusion thereby modifying the stoichiometry of the resulting mixed oxides.

Future study may involve more work on Rietveld Refinement method to better understand crystal structure development and phase evolution during solid state synthesis.

\section{Acknowledgements}

This project is supported by Izmir Institute of Technology (BAP project number: 2011IYTE18). The authors would like to thank IYTE-MAM for their help in analysis of samples and Dr. Aligul Buyukaksoy for his valuable discussions during the preparation of the manuscript.

\section{R E F E R E N C E S}

[1] Singhal SC, Kendall K. High-temperature solid oxide fuel cells fundamentals, Design and Applications. Burlington: Elsevier; 2003.

[2] Jaiswal N, Upadhyay S, Kumar D, Parkash O. Sm3+ and Sr2+ co-doped ceria prepared by citrate nitrate auto-combustion method. Int J Hydrogen Energy 2014;39(1):543.

[3] Singhal SC. Solid oxide fuel cells. The Electrochemical Society Interface. 2007. p. 41-4.

[4] U.S. Department of Energy. Hydrogen and fuel cells. 2013. Retrieved from, http://energy.gov/eere/transportation/ hydrogen-and-fuel-cells.

[5] Minh NQ Takahashi T. Science and technology of ceramic fuel cells. Elsevier Science; 1995.

[6] Appleby J. Fuel cells: trends. In: Research and applications: trends in research \& applications. Hemisphere Publishing; 1987.

[7] Kinoshita K, Cairns EJ. Fuel cells. John Wiley \& Sons, Inc; 2000.

[8] Taniguchi I, Landschoot RCV, Schoonman J. Fabrication of $\mathrm{La}_{1-\mathrm{x}} \mathrm{Sr}_{\mathrm{x}} \mathrm{Co}_{1-\mathrm{y}} \mathrm{Fe}_{\mathrm{y}} \mathrm{O}_{3}$ thin films by electrostatic spray deposition. Solid State Ion 2003;156:1-13.

[9] Suzuki T, Takahashi Y, Hamamoto K, Yamaguchi T, Fujishiro Y. Low temperature processed composite cathodes for solid-oxide fuel cells. Int J Hydrogen Energy 2011;17:10998-1003.

[10] Huijsmans JPP, Berkel FPFV, Christie GM. Intermediate temperature SOFC - a promise for the 21st century. J Power Sources 1998;71:107-10.

[11] Ceram Research. Solid oxide fuel cells. 2001. Retrieved from, http://www.azom.com/article.aspx?ArticleID=919.

[12] AlZahrani A, Dincer I, Xianguo L. A performance assessment study on solid oxide fuel cells for reduced operating temperatures. Int J Hydrogen Energy 2015;24:7791-7.

[13] Jie Yang J, Ji B, Si J, Zhang Q Yin Q Xie J, et al. Synthesis and properties of ceria based electrolyte for IT-SOFCs. Int J
Hydrogen Energy 2016;41(36):15979-84. http://dx.doi.org/ 10.1016/j.ijhydene.2016.04.212. Available online: 10.06.16, ISSN 0360-3199.

[14] Jiang SP. Nanoscale and nano-structured electrodes of solid oxide fuel cells by infiltration: advances and challenges. Int J Hydrogen Energy 2012;37:449-70.

[15] Gwon O, Yoo S, Shin J, Kim G. Optimization of $\mathrm{La}_{1-\mathrm{x}} \mathrm{Sr}_{\mathrm{x}} \mathrm{CoO}_{3-}$ $\delta$ perovskite cathodes for intermediate temperature solid oxide fuel cells through the analysis of crystal structure and electrical properties. Int J Hydrogen Energy 2014;39:20806-11.

[16] Li B, Liu S, Liu X, Hao G, Wang H, Su W. Study on GDC-LSGM composite electrolytes for intermediate-temperature solid oxide fuel cells. Int J Hydrogen Energy 2013;26:11392-7.

[17] Marinha D, Rossignol C, Djurado E. Influence of electrospraying parameters on the microstructure of $\mathrm{La}_{0.6} \mathrm{Sr}_{0.4} \mathrm{Co}_{0.2} \mathrm{~F}_{0.8} \mathrm{O}_{3-\delta}$ films for SOFCs. J Solid State Chem 2009;182:1742-8.

[18] Song HS, Hyun SH, Kim J, Lee HW, Moon J. A nanocomposite material for highly durable solid oxide fuel cell cathodes. J Mat Chem 2008;18:1087-92.

[19] Leng Y, Chan SH, Liu Q. Development of LSCF-GDC composite cathodes for low-temperature solid oxide fuel cells with thin film GDC electrolyte. Int J Hydrogen Energy 2008;14:3808-17.

[20] Baqué L, Padmasree KP, Ceniceros Reyes MA, Troiani H, Serquis A, Soldati A. Improved $\mathrm{Sr}_{0.6} \mathrm{La}_{0.4} \mathrm{Co}_{0.8} \mathrm{Fe}_{0.2} \mathrm{O}_{3-\delta} /$ $\mathrm{Ce}_{0.8} \mathrm{Y}_{0.2} \mathrm{O}_{2-\delta}$ interface for IT-SOFC applications. Int $\mathrm{J}$ Hydrogen Energy 2016;41:1958-65.

[21] Tietz F, Mai A, Stöver D. From powder properties to fuel cell performance - a holistic approach for SOFC cathode development. Solid State Ion 2008;179:1509-15.

[22] Eg G. Services, fuel cell handbook [electronic resource]/EG\&G Technical Services, Inc. Morgantown: U.S. Dept. of Energy, Office of Fossil Energy, National Energy Technology Laboratory; 2004.

[23] Huijsmans JPP. Ceramics in solid oxide fuel cells. Curr Opin Solid State Mater Sci 2001;5:317-23.

[24] Kim C, Kim J, Shin J, Kim G. Effects of composite cathode on electrochemical and redox properties for intermediatetemperature solid oxide fuel cells. Int J Hydrogen Energy 2014;35:20812-8.

[25] Lu K, Shen F. Long term behaviors of $\mathrm{La}_{0.8} \mathrm{Sr}_{0.2} \mathrm{MnO}_{3}$ and $\mathrm{La}_{0.6} \mathrm{Sr}_{0.4} \mathrm{Co}_{0.2} \mathrm{Fe}_{0.8} \mathrm{O}_{3}$ as cathodes for solid oxide fuel cells. Int J Hydrogen Energy 2014;15:7963-71.

[26] Liu Y, Chen K, Zhao L, Chi B, Pu J, Jiang SP, et al. Performance stability and degradation mechanism of

$\mathrm{La}_{0.6} \mathrm{Sr}_{0.4} \mathrm{Co}_{0.2} \mathrm{Fe}_{0.8} \mathrm{O}_{3}-\delta$ cathodes under solid oxide fuel cells operation conditions. Int J Hydrogen Energy 2014;28:15868-76.

[27] Dissemination of IT for the Promotion of Materials Science (DoITPoMS). Fuel cells. 2013. Retrieved from, http://www. doitpoms.ac.uk/tlplib/fuel-cells/intro.php.

[28] Stambouli AB, Traversa E. Solid oxide fuel cells (SOFCs): a review of an environmentally clean and efficient source of energy. Renew Sustain Energy Rev 2002;6:433-55.

[29] Pelosato R, Cristiani C, Dotelli G, Mariani M, Donazzi A, Natali Sora I. Co-precipitation synthesis of SOFC electrode materials. Int J Hydrogen Energy 2013;38:480-91.

[30] Wieczorek-Ciurowa K, Kozak AJ. The thermal decomposition of $\mathrm{Fe}\left(\mathrm{NO}_{3}\right)_{3} \times 9 \mathrm{H}_{2} \mathrm{O}$. J Therm Anal Calorim 1999;58:647-51.

[31] Mansour SAA. Spectrothermal studies on the decomposition course of cobalt oxysalts Part II. Cobalt nitrate hexahydrate. Mater Chem Phys 1994;36:317-23.

[32] Mekhemer GAH, Balboul BAA. Thermal genesis course and characterization of lanthanum oxide. Coll Surf A Physicochem Eng Asp 2001;181:19-29. 
[33] Wendlandt WW. The thermal properties of inorganic compounds III. Strontium chloride 6-hydrate. Thermochim Acta 1975;12:359-66.

[34] Mazan MO, Jerez JM, Soldati A, Nunez P, Larrondo SA. Fedoped ceria nanopowders synthesized by freeze-drying precursor method for electrocatalytic applications. Int $J$ Hydrogen Energy 2015;40:1-9.

[35] Wei ZX, Wang Y, Zhang XJ, Hu CW. Combustion synthesis and effect of $\mathrm{LaMnO}_{3}$ and LaOCl powder mixture on HMX thermal decomposition. Thermochim Acta 2010;499:111-6. 